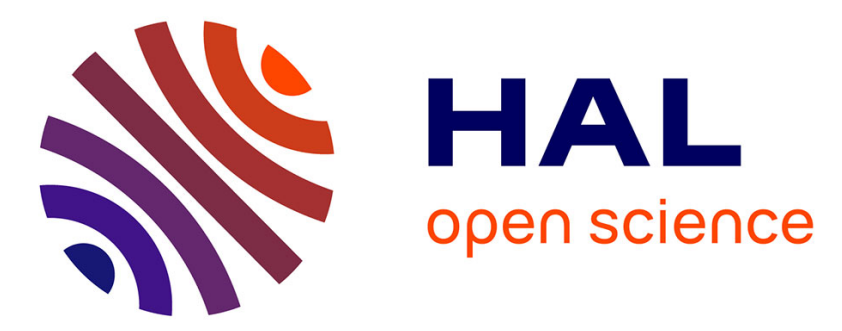

\title{
Comparison of fracture toughness measuring methods applied on silicon nitride ceramics
}

\author{
E. Rudnayová, J. Dusza, M. Kupková
}

\section{To cite this version:}

E. Rudnayová, J. Dusza, M. Kupková. Comparison of fracture toughness measuring methods applied on silicon nitride ceramics. Journal de Physique IV Proceedings, 1993, 03 (C7), pp.C7-1273-C7-1276. 10.1051/jp4:19937196 . jpa-00251829

\section{HAL Id: jpa-00251829 https://hal.science/jpa-00251829}

Submitted on 1 Jan 1993

HAL is a multi-disciplinary open access archive for the deposit and dissemination of scientific research documents, whether they are published or not. The documents may come from teaching and research institutions in France or abroad, or from public or private research centers.
L'archive ouverte pluridisciplinaire HAL, est destinée au dépôt et à la diffusion de documents scientifiques de niveau recherche, publiés ou non, émanant des établissements d'enseignement et de recherche français ou étrangers, des laboratoires publics ou privés. 


\title{
Comparison of fracture toughness measuring methods applied on silicon nitride ceramics
}

\author{
E. RUDNAYOVÁ, J. DUSZA and M. KUPKOVÁ
}

Institute of Materials Research, Slovak Academy of Sciences, Watsonova 47, 04353 Košice, Slovakia

\begin{abstract}
Different fracture toughness testing methods on unreinforced and with $\mathrm{Si}_{3} \mathrm{~N}_{4}$ whiskers reinforced silicon nitride ceramics were compared. The results revealed that in the reinforced ceramics the $K_{I C}$ rises with the increasing of the crack size, which indicates a rising $\mathrm{R}$-curve behaviour in this system. Using IF testing method equations given by Niihara and by shetty proved to have the nearest values to these achieved using SENB in both investigated systems.
\end{abstract}

1. Introduction

Fracture toughness testing of ceramics is hampered by the difficulties associated with introducing a stable straight crack or a sharp notch into these materials. Different testing methods were used for these measurements by different authors. They achieved different $K_{\text {IC }}$ values even in the same material [1-4]. The most widespread fracture toughness measuring methods are:

- bending tests with straight through notch (SENB), Chevron notch (CHN) and indentation strength using vickers indentation cracks (IS) or controlled surface flaw using knoop indentation cracks (CSF);

- indentation fracture measurements (IF).

Each of these techniques has its advantages and disadvantages. IF and Is are simple, but less reproducible. SENB gives reliable results if the notch is sharp enough $(<100 \mu \mathrm{m})$. By using IF, there are problems with the surface preparation and with the influence of the preparation mode on the measured $K_{\text {Ic }}$ values.

The aim of this study is to compare and to judge the suitability in using some of these methods on two types of ceramics, i.e. on unreinforced and with $\beta-\mathrm{Si}_{3} \mathrm{~N}_{4}$-whiskers reinforced silicon nitride systems.

2. Experimental Procedures

The unreinforced material was a hot pressed silicon nitride with $\mathrm{Al}_{2} \mathrm{O}_{3}$ and $\mathrm{Y}_{2} \mathrm{O}_{3}$ as sintering additives. The reinforced system was a hot pressed ( $\left.1750{ }^{\circ} \mathrm{C} / 32 \mathrm{MPa}\right) \mathrm{Si}_{3} \mathrm{~N}_{4}$ with 20 wt\% of $\beta-\mathrm{Si}_{3} \mathrm{~N}_{4}$ whiskers containing the same additives [5]. The characteristic microstructures of both systems are in Fig.1 a,b. Samples for fracture toughness measurements were cut from billets so as their tensile face were 
perpendicular to the hot pressing direction, and ground parallel to the longitudinal axis to $3 \times 4 \times 45 \mathrm{~mm}$. The tensile surface was carefully polished and indented with the Vickers pyramid using loads from 49 to $196 \mathrm{~N}$. All specimens were annealed at $1000 \mathrm{o} / 2 \mathrm{~h}$ in air before indentation. The fracture toughness of the studied systems was assessed using the following methods:

a) Indentation strength in bending (ISB)

The indents were made carefully to cause cracks perpendicular to the longitudinal axis of the specimens. The indented bars were broken in four-point bending with a lower span of $40 \mathrm{~mm}$ and upper span of $20 \mathrm{~mm}$, at the cross head rate of $0.5 \mathrm{~mm} / \mathrm{min}$. The $k_{T C}$ values were determined according to the equation published by Marshaff et al. [6].

b) Modified indentation strength method (MIS)

Each specimen used in this method was indented three times, using the same load. Then they were broken in the way described in a). The crack lengths were measured before and after the specimen's failure using an optical microscope. Fracture toughness was calculated by MIs from the equation developed by Cook and Lawn [7].

c) Indentation fracture (IF)

There were made from 10 to 15 indents at each load on the very carefully prepared surfaces of samples. The diagonals of indents and the crack lengths were measured microscopically using calibrated eyepiece graticule. The crack type in each sample was determined by serial sectioning and the remaining crack length was measured after each step to generate the crack contour. The IF values were computed using equations published in [8-13].

d) Single edge notched beam (SENB)

The samples were notched by a $0.1 \mathrm{~mm}$ thick diamond wheel resulting in a notch root radius about $0.05 \mathrm{~mm}$. The notch depth to specimen thickness ratio was about 0.2 . The exact depth was measured microscopically. Tests were performed in 4-point bending with an outer span of $32 \mathrm{~mm}$ and an inner span of $16 \mathrm{~mm}$ at a crosshead speed 0.5 $\mathrm{mm} / \mathrm{min}$. The fracture toughness was computed using the equation published in $[14]$.
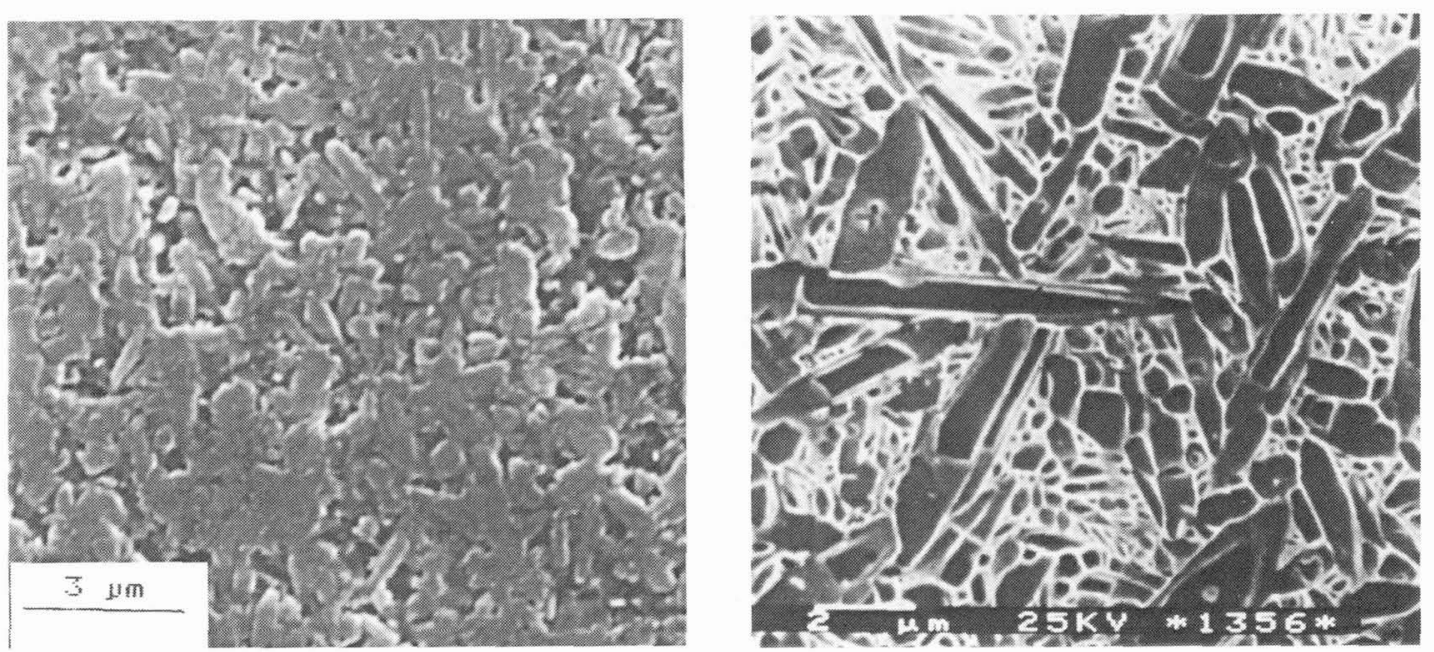

Fig. Ia,b Microstructure of $\mathrm{Si}_{3} \mathrm{~N}_{4}$ and $\mathrm{Si}_{3} \mathrm{~N}_{4}+20 \% \beta-\mathrm{Si}_{3} \mathrm{~N}_{4}$ whisker systems 
3. Results and Discussion

Results of serial sectioning revealed that in both systems the indented crack shapes were closer to the Palmquist type (cracks did not remained connected after polishing away the surface layer of the indent), but they were deeper than in the case of typical palmquist crack. The fracture toughness values are presented in Tabs. I and II. Fracture toughness values achieved by IS method showed a rising tendency with the rise of $\mathrm{c} / \mathrm{a}$ ratio in both systems. But this tendency is more remarkable in the case of the reinforced system. Comparing the $K_{\text {IC }}$ values measured by SENB with those achieved by IF method computed using equation of Niihara et al. for Palmquist crack type [11] and that of shetty [13] showed that these two equations gave the most reliable results for both investigated materials. Results computed according to the Laugier equation [14] had a falling tendency with rising of c/a. The MIS method overestimated the fracture toughness values in both materials.

Table I. Fracture Toughness Tests Results on Unreinforced $\mathrm{Si}_{3} \mathrm{~N}_{4}$

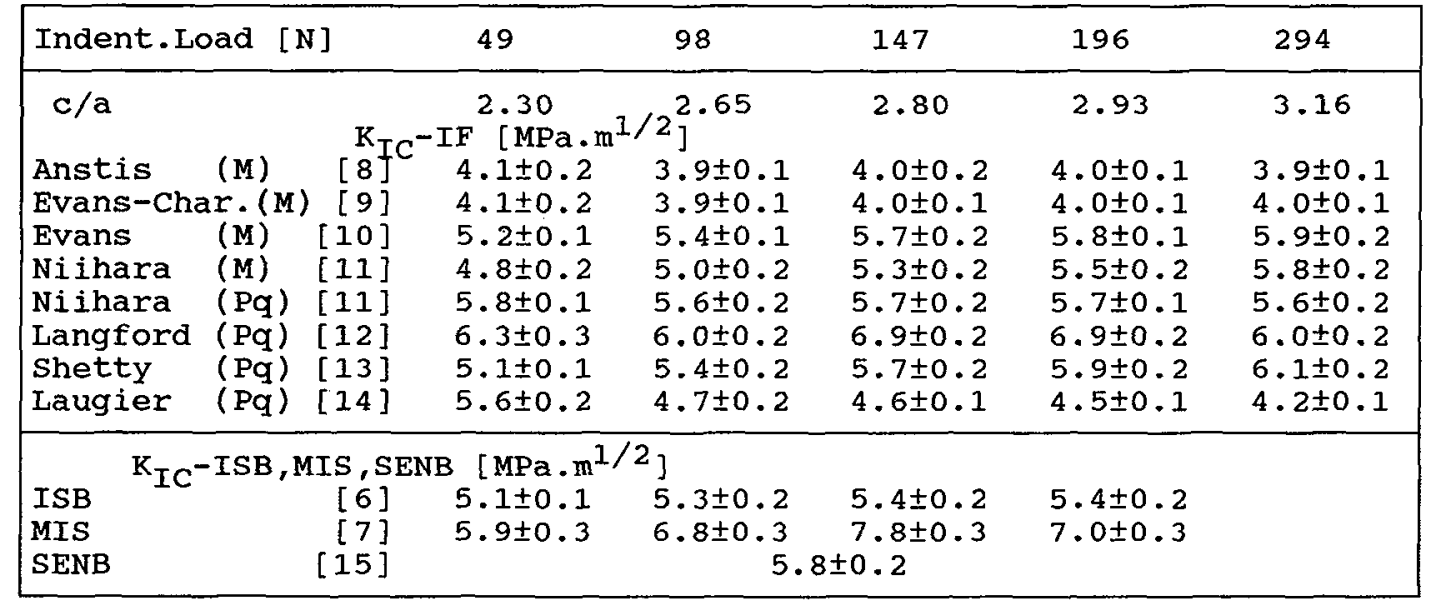

TABLE II. Fracture Toughness Tests Results on Reinforced $\mathrm{Si}_{3} \mathrm{~N}_{4}$

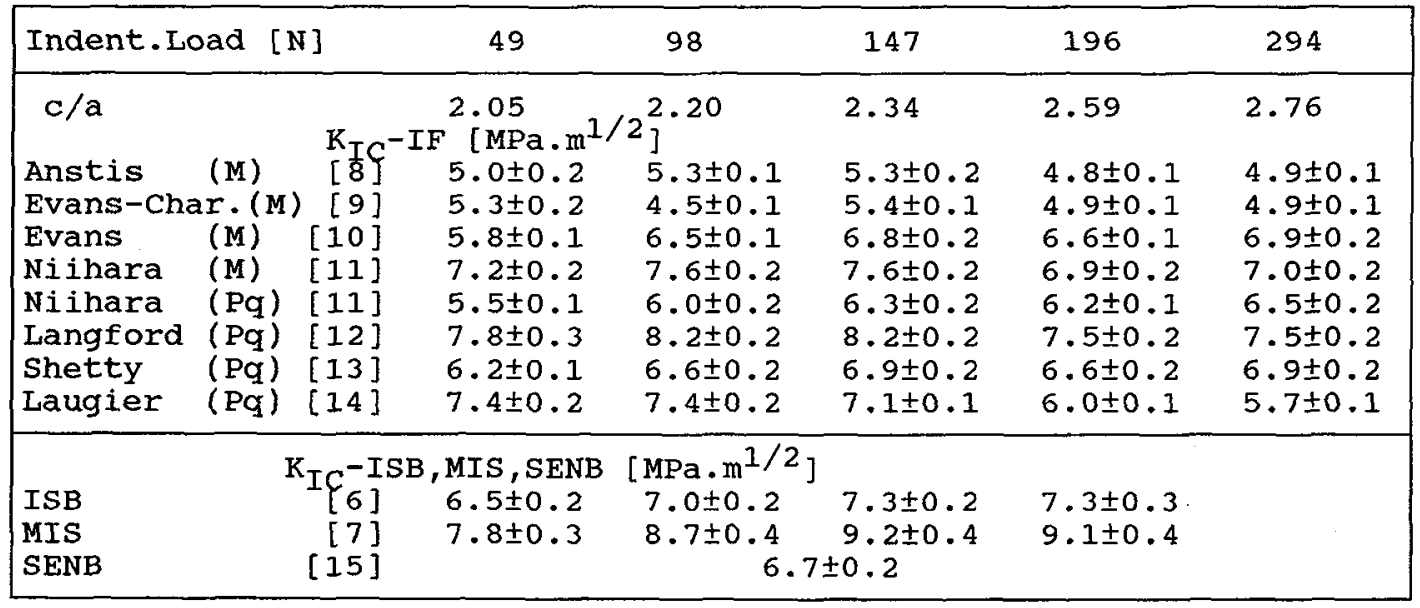

$c=$ crack length, $a=$ diagonal length, $(M)$ - equation for median crack type, (Pq) - equation for Palmquist crack type 
Fractographic analysis of fracture surfaces and fracture lines revealed a very fine grain size in the unreinforced system. The observed fracture micromechanisms correspond with this fine microstructure. The intercrystalline fracture was identified predominantly, with the exception of some cases in which the transgranular fracture of larger $\mathrm{Si}_{3} \mathrm{~N}_{4}$ grains was detected. From the characteristic toughening mechanisms, which include crack deflection, crack bridging, and pull out of whisker shaped grains, only the crack deflection was identified in Iimited cases. The fine grained globulitic microstructure limits the occurrence of toughening mechanisms and this causes relatively low fracture toughness values.

In the reinforced $\mathrm{Si}_{3} \mathrm{~N}_{4}$ ceramics different types of toughening mechanisms were found (crack deflection, crack bridging by $\mathrm{Si}_{3} \mathrm{~N}_{4}$ whiskers, mechanical interlocking and sliding between both separated fracture surfaces). This system showed a rising $\mathrm{R}$-curve behaviour $(\beta=0.19)$, while the low grained unreinforced $\mathrm{Si}_{3} \mathrm{~N}_{4}$ had a nearly flat $R$-curve $(\beta=0.32)$. This is also of importance when comparing the results of $K_{I C}$ measurements of both systems, especially those obtained by IF and ISB methods.

\section{Conclusions}

The indentation crack profile was more or less of Palmquist type in the whole range of used indentation loads (49-294 N) in both investigated materials. By using indentation fracture measurements the best correlating values with the SENB method gave equations published by shetty and by Niihara for both systems. In case of reinforced system the determination of the true $K_{I C}$ value is further complicated by its rising R-curve behaviour.

The authors would like to express their thanks to P.Šajgalík for preparation of the material and $\mathrm{L}$. Kovác for providing mechanical tests.

References

[1] C. Rief and K. Kromp, Int.J.High Tech.Ceram. 4, (1988) 301

[2] G. Himsolt, T. Fett, K. Keller and D. Munz, Mat.-Wiss. u.Werkst. 20,148 (1989)

[3] A. M. El Aslabi, G. Kleist, R. W. Steinbrech and H. Nickel, in Fortschritt. der Deutsch. Ker. Ges., Band 6, 133 (1991)

[4] J.Dusza, Scripta Metall. et Mater.,26 (1992),337-342.

[5] P. Šajgalik, M.J.Hoffmann, Reinforced $\mathrm{Si}_{3} \mathrm{~N}_{4}$ Ceramics - Relationship among Microstructure, strength, Toughening Mechanisms and Fracture Toughness, Proc.Int.Conf.ENGINEERING CERAMICS'92 (Reproprint Bratislava 1993), 89-101.

[6] P.Chantikul, G.R.Anstis, B. R. Lawn and D. B. Marshall, J. Am. Ceram. Soc. 64,539 (1981)

[7] R. F. Cook and B. R. Lawn, J.of the Am. Ceram. Soc.,66, C-200 1983

[8] G. R. Anstis, P. Chantikul, B. R. Lawn and D. B. Marshall, J. Amer. Ceram. Soc. 64,533 (1981)

[9] A. G. Evans and E. A. Charles, J. Am. Ceram. Soc.,59, 371 (1976)

[10] A. G. Evans, in Fracture mechanics applied to brittle materials, ASTM STP 678, Am. Soc. for Testing and Materials, 112 (1979)

[11] K. Niihara, R. Morena and P. H. Hasselman, J. of Mat. Sci. Lett., 1, 13 (1982) [12] J. Langford, J. Mat. Sci. Letters, 1, 193 (1982)

[13] D. K. Shetty, I. G. Wright, P. N. Mincer and A. H. Clauer, J. Mat. Sci., 20, 1873 (1985)

[14] M. T. Lauger, J. Mater. Sci. Letters, 6, 355 (1987)

[15] D.Munz and T.Fett, Mechanisches Verhalten keramischer Werkstoffe, Springer Verl., Berlin-Heidelberg, 1989. 